\title{
Editorial: Planning and Development of Defense Institutions in a Time of Transformation
}

\section{Thomas-Durell Young and Todor Tagarev}

One could make a persuasive argument that all countries either are at present, or will be in the near future, undergoing some form of a process that can be described as "defense reform." A reduction in the defense budget, as has happened in most NATO and Partnership states, or a significant change in policy direction-e.g., the Bush Administration's "defense transformation" strategy-will result in a spate of defense reform. However, an equally persuasive argument can be made that long-standing democracies (such as those nations within the Alliance) are particularly well equipped to undertake such re-organizations, given the strength of their defense institutions. Such strength is characterized by the following qualities: a constructive, consensus-based inter-ministerial consultative process; a cadre of educated and experienced civilian defense officials within the Ministry of Defense and national defense headquarters; the presences of defense experts in key civilian ministries (most importantly, the Ministry of Finance); carefully promulgated (and vetted) laws relating to defense; and an experienced body of professional military officers, who are well versed in the realities of civilian control of the military. One should note, for example, that, based on recent experiences with defense reductions in Great Britain and the Netherlands, defense reforms can be confusing to the public and painful to execute from within the defense community, even when these advantages are present.

Consider, therefore, the plight of a young democracy with weak institutions, insufficiently educated and trained defense officials and senior military officers, legacy bureaucratic structures, an imperfect codex of defense legislation, and a dysfunctional inter-ministerial consultative process. Given the extent of the challenges presented by defense reform, it is little wonder that the effort to undertake such reforms is likely to appear all but insurmountable in such a state, and for good reason.

Therefore, one should give a favorable assessment to the declaration of 7 June 2004 by the Euro-Atlantic Partnership Council of a new Partnership Action Plan on Defense Institution Building (PAP-DIB). To be sure, there is little new in what has become known as the "Ten Commandments" of PAP-DIB: ${ }^{1}$

1. Develop effective and transparent arrangements for the democratic control of defense activities, including appropriate legislation and coordination arrangements setting out the legal and operational role and responsibilities of key state institutions in the legislative and executive branches of government.

1 Euro-Atlantic Partnership Council, Partnership Action Plan on Defense Institution Building (PAP-DIB) (Brussels: NATO Basic Texts 7 June 2004), available at www.nato.int/docu/ basictxt/b040607e.htm. 
2. Develop effective and transparent procedures to promote civilian participation in developing defense and security policy, including participation of civilians in governmental defense institutions, cooperation with non-governmental organizations, and arrangements to ensure appropriate public access to information on defense and security issues.

3. Develop effective and transparent legislative and judicial oversight of the defense sector, including appropriate arrangements to ensure due legal process.

4. Develop effective and transparent arrangements and procedures to assess security risks and national defense requirements; develop and maintain affordable and interoperable capabilities corresponding to these requirements and international commitments, including those within the framework of PfP.

5. Develop effective and transparent measures to optimize the management of defense ministries and agencies with responsibility for defense matters and associated force structures, including procedures to promote inter-agency cooperation.

6. Develop effective and transparent arrangements and practices to ensure compliance with internationally accepted norms and practices established in the defense sector, including export controls on defense technology and military equipment.

7. Develop effective and transparent personnel structures and practices for defense forces, including training and education, promotion of knowledge of international humanitarian law, arrangements for transparent promotion and career development, and for the protection of the civil rights and freedoms of members of the armed forces.

8. Develop effective and transparent financial, planning, and resource allocation procedures in the defense area.

9. Develop effective, transparent, and economically viable methods for the management of defense spending, taking into account macroeconomic affordability and sustainability; develop methods and policies in order to cope with the socio-economic consequences of defense restructuring.

10. Develop effective and transparent arrangements to ensure effective international cooperation and promote neighborly relations in defense and security matters.

Rather, the true value of PAP-DIB is to better align the orientations of member nations of both the Partnership and NATO to addressing what is admittedly a considerable amount of unfinished business in the area of defense rationalization and reform. By placing defense reform within the useful context of the Planning and Review Process, PAP-DIB brings to bear the attention necessary for both reforming countries and for those engaged in providing them with needed technical assistance in defense reform and in adapting Western norms of civilian control of the military and transparent planning and execution. If nothing else, defense officials and military officers from Allied and Partner nations should come to identify PAP-DIB with national defense reform. All efforts that are initiated to achieve the PAP-DIB objectives will inexorably assist in effecting national defense reform. Indeed, while perhaps verging on impertinence, one 
might well argue that PAP-DIB could be even more important for NATO nations that it is for their partners, because it has brought the subject of defense institution building to the forefront of policy deliberations within the Alliance, as well as within the context of $26+1$ deliberations.

This special edition of Connections was conceived by the Consortium of PfP Defense Academies and Security Studies Institutes to serve as an initial step toward a constructive dialogue on the question of what constitutes effective defense institution building. In this issue, the editors have attempted to bring together a series of practically-focused essays that address specific areas of defense planning and transformation. Readers will find essays on principles, best practices, and case studies in defense policy-making, capability-based planning, defense resource management, and acquisition management, as well as information on technical assistance, education, and training resources available for reforming Partner countries. We hope that readers who are interested in enhancing existing defense planning mechanisms will find in this publication ideas on how to match capabilities with security risks, defense requirements, and available resources; how to increase the effectiveness and the transparency of financial, planning, and resource allocation procedures; and how, in general, to enhance the effectiveness of their efforts toward managing defense ministries and armed forces.

Certainly, the literature of defense reform is in need of both growth and enrichment. If these essays encourage defense experts to document the experiences of successes and failures of other nations in the reform of defense structures, procedures, and management, then all nations - whether Allies, Partners, or otherwise - will be the better for their efforts. It is clear that best practices in defense reform can be discerned by studying successful reforms, but they can also be gleaned from examining what has failed, and why. Moreover, let us be clear and forceful in arguing that the experiences of small, reforming nations in defense institution building are equally legitimate contributions to our collective understanding of best practices as are those derived from long-established and large democracies. Best practices can be applied across borders and in different contexts, yet we should also keep in mind that what has worked in one nation may not work everywhere else. Thus, the more Allies and Partners can identify and document best practices, the better will be the understanding in all nations of how best to achieve the elusive and perennially challenging task of undertaking defense reform. 
THE QUARTERLY JOURNAL

\section{Bibliography}

Euro-Atlantic Partnership Council, Partnership Action Plan on Defense Institution Building In (PAP-DIB). Brussels: NATO Basic Texts , 2004. 